\title{
Article \\ Replicative Deformed Wing Virus Found in the Head of Adults from Symptomatic Commercial Bumblebee (Bombus terrestris) Colonies
}

\author{
Giovanni Cilia (D), Laura Zavatta, Rosa Ranalli, Antonio Nanetti * ${ }^{\mathbb{D}}$ and Laura Bortolotti \\ CREA Research Centre for Agriculture and Environment, Via di Saliceto 80, 40128 Bologna, Italy; \\ giovanni.cilia@crea.gov.it (G.C.); laura.zavatta@crea.gov.it (L.Z.); rosa.ranalli@crea.gov.it (R.R.); \\ laura.bortolotti@crea.gov.it (L.B.) \\ * Correspondence: antonio.nanetti@crea.gov.it
}

check for updates

Citation: Cilia, G.; Zavatta, L.; Ranalli, R.; Nanetti, A.; Bortolotti, L. Replicative Deformed Wing Virus Found in the Head of Adults from Symptomatic Commercial Bumblebee (Bombus terrestris) Colonies. Vet. Sci. 2021, 8, 117. https://doi.org/ $10.3390 /$ vetsci 8070117

Academic Editor: Yanping

(Judy) Chen

Received: 20 May 2021

Accepted: 21 June 2021

Published: 23 June 2021

Publisher's Note: MDPI stays neutral with regard to jurisdictional claims in published maps and institutional affiliations.

Copyright: (c) 2021 by the authors. Licensee MDPI, Basel, Switzerland. This article is an open access article distributed under the terms and conditions of the Creative Commons Attribution (CC BY) license (https:/ / creativecommons.org/licenses/by/ $4.0 /)$.

\begin{abstract}
The deformed wing virus (DWV) is one of the most common honey bee pathogens. The virus may also be detected in other insect species, including Bombus terrestris adults from wild and managed colonies. In this study, individuals of all stages, castes, and sexes were sampled from three commercial colonies exhibiting the presence of deformed workers and analysed for the presence of DWV. Adults (deformed individuals, gynes, workers, males) had their head exscinded from the rest of the body and the two parts were analysed separately by RT-PCR. Juvenile stages (pupae, larvae, and eggs) were analysed undissected. All individuals tested positive for replicative DWV, but deformed adults showed a higher number of copies compared to asymptomatic individuals. Moreover, they showed viral infection in their heads. Sequence analysis indicated that the obtained DWV amplicons belonged to a strain isolated in the United Kingdom. Further studies are needed to characterize the specific DWV target organs in the bumblebees. The result of this study indicates the evidence of DWV infection in B. terrestris specimens that could cause wing deformities, suggesting a relationship between the deformities and the virus localization in the head. Further studies are needed to define if a specific organ could be a target in symptomatic bumblebees.
\end{abstract}

Keywords: bumblebee; commercial Bombus terrestris; spillover; DWV; honey bee pathogens; replicative virus; strand-specific RT-PCR

\section{Introduction}

The deformed wing virus (DWV) belongs to the Picornaviridae family, within the Iflavirus genus, with a positive-sense ssRNA [1,2]. As an Apis mellifera pathogen, DWV is deemed to be involved in colony losses and, as such, a significant impact to the ecosystem $[3,4]$. The virus is spread globally $[1,2,5,6]$, and DWV infections are generally detected due to the presence of symptomatic honey bees, characterized by deformed or missing wings and shortened abdomens [1]. Presently, three genetic DWV variants are acknowledged and named as type A, B, and C [7,8], with type A being the most prevalent [8].

In honey bees, DWV is usually associated with Varroa destructor infestations, even if, in some cases, the virus was detected in Varroa-free bees [9]. Within the colony, it is transmitted by the punctures produced in both the juvenile and adult stages [10], but the infection may also spread horizontally by bee-to-bee contact [11-15] and ingestion of contaminated food [16-18]. However, due to the multiple possible transmission routes, DWV may spillover to other sympatric Hymenopterans [19-21], including species used in commercial pollination [22-26] and beetles [27].

Bumblebees are among the most common and widespread bee pollinators, mainly in temperate and cold areas. Due to their unique ability to pollinate tomato crops, they began to be bred and sold in many countries for pollination purposes [28]. Bumblebee rearing and trading date back to the 1980s, when the first company for the commercial 
rearing of B. terrestris was founded in Belgium. Bumblebees were initially used for tomato pollination in greenhouses, but later they extended to other crops both in open fields and greenhouses. Presently, bumblebees are commercially bred in all continents, except Africa, with a global sales volume exceeding 1,000,000 colonies per year. They are sold worldwide, with the main exception of mainland Australia. Due to the emerging risks in the marketing of non-native species and the resulting restrictions, many local species of bumblebee began to be bred for pollination in the countries of origin, but $B$. terrestris always remains the most used and widespread in Europe, North Africa, and West Asia [29,30].

One of the main concerns in the commercialization of bumblebees is the spread of diseases and pathogens [31]. Commercial bumblebee colonies can suffer from various diseases and pests, which can affect their survival. Those that can cause major problems are the protozoan Nosema bombi, the tracheal mite Locustacarus (Bombacarus) buchneri, the Trypanosomatidae Crithidia bombi, and the brood parasites Melittobia acasta and M. chalybii, whose massive presence in breeding facilities requires the stamping out of the infected colony and, in the most severe infestations, of the entire production stock [32-35]. Other less dangerous but still problematic pests are the pyralid moths Vitula edmandsii and Plodia interpunctella whose larvae feed primarily on bumblebee food stores but occasionally also on bumblebee brood [29].

Thus far, viral infections have not been considered major threats for wild and commercial bumblebees. However, recent findings show the presence of replicative honey bee viruses in wild bees, including bumblebees. The infection with some of these viruses proved to cause negative consequences in B. terrestris, such as reduced fecundity and colony founding associated with Kashmir bee virus (KBV), reduced fecundity due to Israeli acute paralysis virus (IAPV), and mortality due to acute bee paralysis virus (ABPV) [36-39]. Conversely, B. terrestris infection with DWV has been found to result in wing deformities and mortality in a limited number of individuals $[40,41]$. A recent investigation showed that DWV could replicate in Bombus pupae after artificial infection and larval feeding of virus-contaminated food, but none of the infected bumblebees showed signs of wing deformities [23].

Since bumblebees are not affected by Varroa infestations, it remains unclear how the infection occurs under natural conditions, although DWV-positive Bombus sp. Were found in areas with a high DWV prevalence in Apoidea species [40,42-44]. Possibly, the virus transmission between sympatric pollinator species is mediated by shared floral resources such as pollen $[16,24]$. Similarly, in commercial breeding, the most likely infection route is by feeding the bumblebees with pollen from honey bee colonies. In effect, batches of honey bee pollen used to feed bumblebees revealed the presence of several pathogens (Crithidia spp., Ascosphaera bombi, A. apis, Nosema ceranae, Nosema thomsoni, Microsporidium $\mathrm{sp}$. Oise), including viruses (sacbrood virus-SBV, DWV, IAPV, and chronic bee paralysis virus-CBPV) [45]. This study aimed to investigate the DWV distribution in the body of symptomatic and asymptomatic Bombus terrestris specimens reared in a commercial colony after the first detection in a worker with relevant wing deformities.

\section{Materials and Methods}

\subsection{Sample Collection}

On 15 January 2021, three commercial bumblebee colonies (B. terrestris) arrived from a North European breeding company to our laboratory (Bologna, Italy) for an experimental test requiring colonies in an advanced stage of development. The colonies contained about a hundred workers and pupal stages of gynes and males. Moreover, they appeared healthy and in good condition, although the founder queen was found dead in all of them. The colonies were kept in a climate room for a total of three weeks, under constant environmental conditions of temperature $\left(25 \pm 1{ }^{\circ} \mathrm{C}\right)$ and relative humidity $(40 \pm 10 \%)$. Darkness (0:24 L:B) was maintained throughout the rearing period, and all the laboratory manipulations were conducted with the aid of red lights [46]. Flight activity was not allowed. The colonies had arrived from the breeding company with food supplies that 
were integrated onsite with frozen pollen from local honey bee colonies. On 17 January 2021, a routine check allowed for the detection in one of the colonies of one worker with crippled wings (Figure 1).

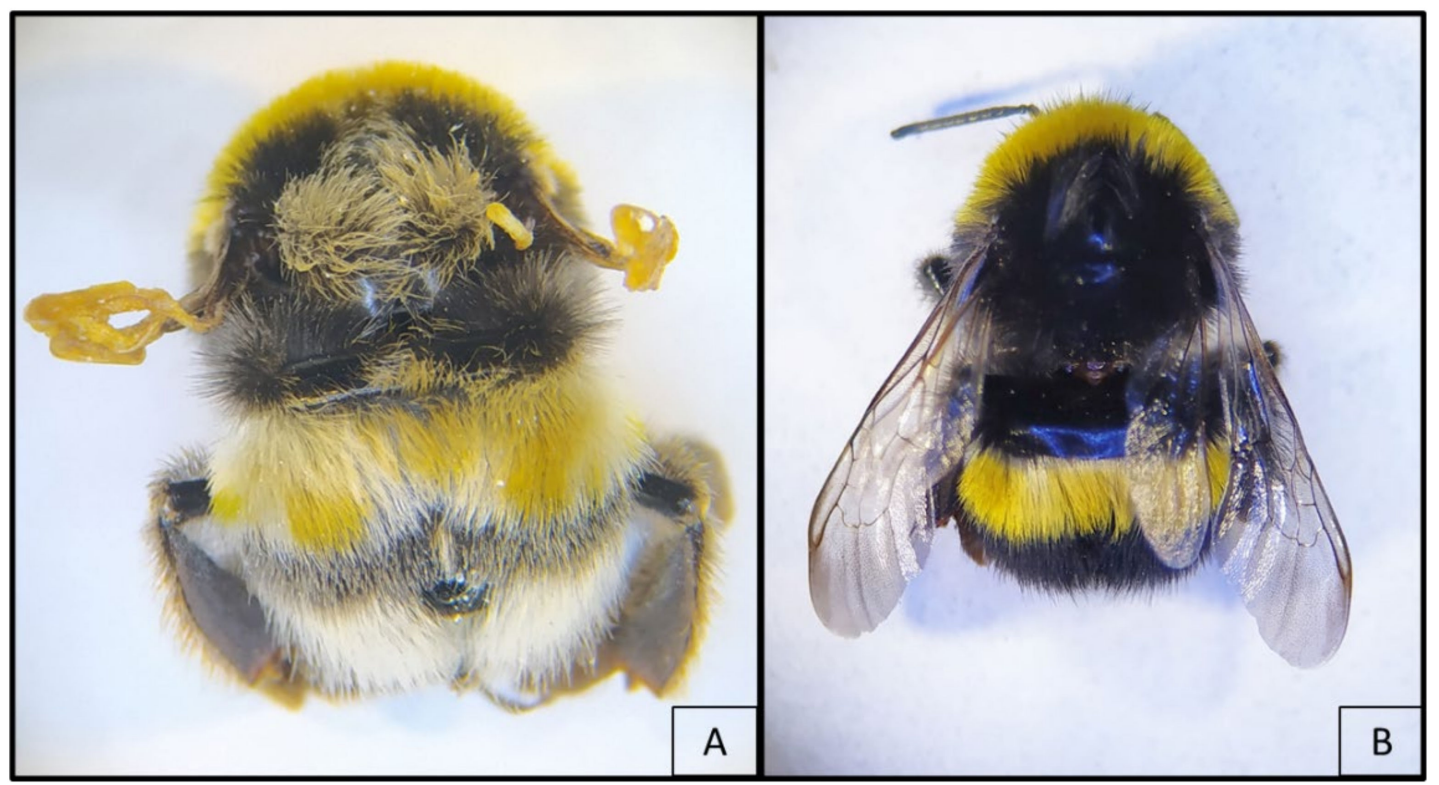

Figure 1. Bombus terrestris workers with crippled (A) and normal (B) wings. Individual A shows yellow and white patches of anomalous pigmentation.

As this observation was compatible with a DWV infection, a sampling plan created to collect and analyse all kinds of individuals present in the colonies. Accordingly, the following asymptomatic individuals were sampled from each colony: five gynes, five workers, five males, five pupae, five larvae, and three pools of eggs $(n=5)$. All the adults that were found with crippled wings were also individually collected.

\subsection{Extraction of Total RNA}

Before dissection and extraction of viral RNA, all samples were washed, through full immersion in $95 \%$ ethanol for $10 \mathrm{~s}$ to remove any external viral contamination that may have been present. Each adult was dissected under sterile conditions with a scalpel to exscind the head from the rest of the body (thorax and abdomen), which were collected in separate 2-ml microtubes. To avoid possible cross contamination, new scalpels were used for each individual. The juvenile stages (pupae, larvae, and the pool of eggs) were introduced undissected into separate $2-\mathrm{ml}$ microtubes. Beads and $80 \mu \mathrm{L}$ of Lysis Buffer provided by GeneJET RNA Purification Kit (ThermoFisher Scientific, Waltham, MA, USA) were added to each sample, which was crushed with a TissueLyser II (Qiagen, Milan, Italy) for $3 \mathrm{~min}$ at $25 \mathrm{~Hz}$, as previously described [47,48].

Total RNA was extracted from each sample with GeneJET RNA Purification Kit (ThermoFisher Scientific, Waltham, MA, USA) following the manufacturer's instruction. All samples were eluted in 1001 RNase-free water. The RNA extracts were stored at $-80{ }^{\circ} \mathrm{C}$ until use. High pure sterile DNA- and RNA-free water was used as a negative control in all analytical steps.

\section{3. qRT-PCR Assays to Detect and Quantify the Deforming Wing Virus (DWV)}

The extracted RNAs were analysed by qRT-PCR to detect and quantify the presence of DWV in bumblebees. Primers amplified a 132-bp fragment within the highly conserved region coding for the RNA-dependent RNA polymerase $(R d-R p)$ commonly expressed in all virus variants. The sequences were: DWV Fw 5' - TTTGACATTGAGCTACAAGACTCG-3' (nt. 8685-8708), DWV Rev 5' - ACAATCCGTGAATATAGTGTGAGG-3' (nt. 8816-8793) [16]. 
The viral genomes were amplified using Power SYBR ${ }^{\circledR}$ Green RNA-to-Ct ${ }^{\mathrm{TM}}$ 1-Step Kit (ThermoFisher Scientific, Waltham, MA, USA), following the manufacturer's instruction. The qPCR assay was performed on Applied Biosystems ${ }^{\circledR} 7500$ fast and 7500 Real-Time PCR (ThermoFisher Scientific, Waltham, MA, USA). For the target gene, a total reaction volume of $20 \mu \mathrm{L}$ was used following the protocols previously described [16,19].

The successful amplification of reference gene $\beta$-Actin, with the previously described primers [49], was used to confirm the sample integrity from the RNA extraction to the qPCR analysis and to normalize the results to reach an absolute quantification.

Virus loads were quantified with absolute quantification of number of DWV copies in each ng of RNA (copies/ng RNA). The amplified fragment was gel purified using GeneJET Gel Extraction and DNA Cleanup Micro Kit (ThermoFischer Scientific, Waltham, MA, USA) and cloned using CloneJET PCR Cloning Kit with DH10B Competent Cells (ThermoFischer Scientific), following the manufacturer's instructions, and sequenced (BMR Genomics, Padova, Italy). Following plasmid DNA removal by RNase-free DNase treatment (RNase Free DNase Set, Qiagen, Hilden, Germany), the transcript was purified and concentrated with the RNeasy Minelute Cleanup Kit (Qiagen, Hilden, Germany) and quantified with the Quant-iT ${ }^{\mathrm{TM}}$ RiboGreen ${ }^{\mathrm{TM}}$ RNA Assay Kit (ThermoFisher, Waltham, MA, USA). A standard curve was created with six tenfold dilutions of cloned RNA fragment $\left(2 \times 10^{5}\right.$ to 2 copies/ng) [16].

\subsection{Strand-Specific RT-PCR}

The DWV replication was evaluated through a strand specific RT-PCR using specific primers Fw 8450: 5'- TGGCATGCCTTGTTCACCGT-3' (nt. 8450-8469) or Rev 8953: 5' CGTGCAGCTCGATAGGATGCCA-3' (nt. 8953-8932), which amplify a 504-bp fragment of the $R d-R p$, as previously described [16] . All amplicons were visualized on a $1.5 \%$ agarose gel.

The DWV sequence described in this study was submitted to the GenBank database under the accession number MZ222242.

\subsection{Phylogenetic Analysis}

The strand specific RT-PCR-obtained amplicons were sequenced (BMR Genomics, Padua, Italy) and analysed using BLASTn to standard databases with default parameters for megablast [50]. The sequences with a high Max Score and a Query $\geq 70 \%$ in the BLAST analysis were selected to build the phylogenetic tree. The phylogenetic analysis was performed by the maximum likelihood method based on the Tamura-Nei model with a bootstrap test using MEGA software [51].

\subsection{Statistical Analysis}

As the batch of colonies was provided by the same producer and all of them were prevented from flying, the 'colony' as an explanatory factor for the DWV titre was considered unimportant. This consideration elicited the decision to pool the data together by the kind of individual, as if they all belonged to the same colony.

The results were analysed with a parametric approach. Before the statistical analysis, significant violations to the assumptions of parametric tests were removed by log transformation of data. However, text and illustrations report untransformed data.

The number of DWV copies detected in the dissected body parts from the same adult was summed up to calculate the total individual DWV titre. This was considered as the dependent variable in a one-way analysis of variance (ONE-WAY ANOVA) with the "kind of individual' (deformed adults, gynes, workers, males, pupae, larvae, and eggs) as the categorical factor.

A factorial ANOVA was conducted on the amount of DWV copies detected in the adults against the categorical independent variables 'kind of individual' (deformed adults, gynes, workers, males) and 'body part' (head, rest of the body). The interaction between the two factors mentioned above was also calculated. 
When the F-test resulted in a significant effect, a pairwise Newman-Keuls post hoc test was conducted to spot significant differences between the groups.

For all tests, the protection level from statistical Type I error was set at $p \leq \alpha=0.05$.

\section{Results}

Wing deformity (Figure 2) was detected in adults of all colonies. In detail, the deformities were found, respectively, in one and six workers of two colonies and in four workers and one newly hatched male (Figure $2 \mathrm{~B}$ ) of the third one.

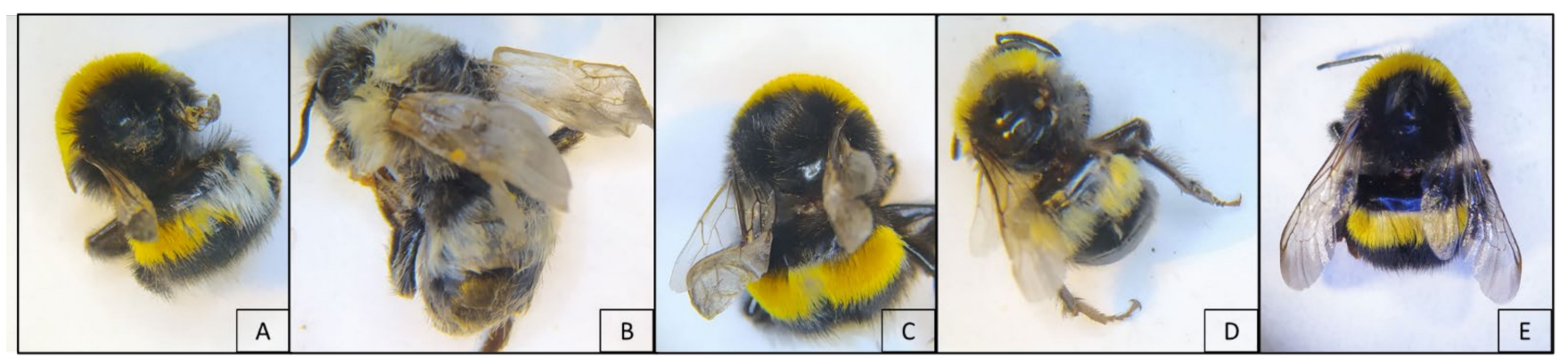

Figure 2. Evidence of several degrees of wing deformities in symptomatic DWV infected Bombus terrestris. Wings of adult bumblebees from the inspected colonies: bilateral $(\mathbf{A}, \mathbf{C})$ and unilateral (D) deformity in workers; bilateral deformity in newly hatched male (B); asymptomatic worker (E). Deformed individuals show yellow and white patches of anomalous pigmentation.

All samples scored positive for DWV, with a number of genomic copies ranging from $2.01 \times 10^{2}$ to $5.10 \times 10^{6}$. The viral titre varied significantly in the different kinds of individuals that were sampled $(F(6,69)=6.130, p=0.000)$; a Newman-Keuls test showed that the amount of DWV copies was significantly higher in the deformed adults compared to the asymptomatic adults and the eggs, larvae, and pupae). Among the nondeformed individuals, no significant differences were detected despite belonging to different stages, sexes, and castes (Figure 3).

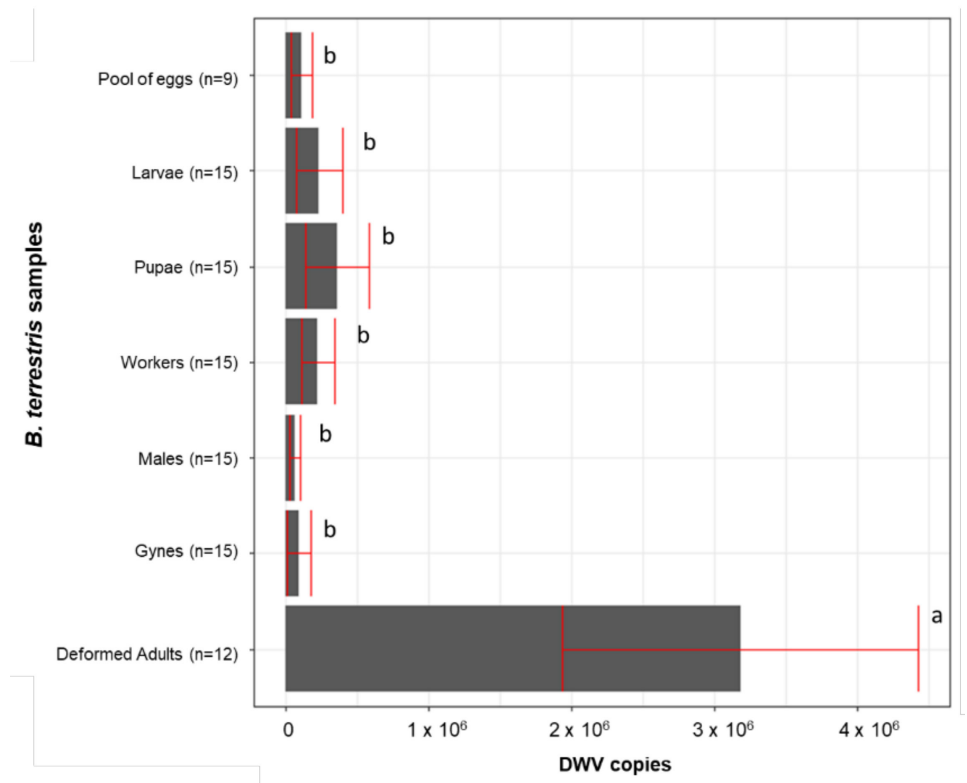

Figure 3. DWV titre of deformed and asymptomatic adults and juvenile individuals. Averages $+/-$ standard error are shown. The same letter indicates a nonsignificant difference.

In the adults, the DWV titre was significantly influenced by the kind of individual ( $\mathrm{F}(3$, $66)=127.687, p=0.000)$, the body part $(\mathrm{F}(1,66)=337.772, p=0.000)$, and their interaction 
$(F(3,66)=36.342, p=0.000)$. A Newman-Keuls test did not show a significantly different DWV abundance in the head and the rest of the body of deformed individuals. However, all the considered types of asymptomatic adults had significantly fewer copies in their heads. Furthermore, in both the heads and the rest of the body of deformed individuals, the number of DWV copies was significantly higher compared to the asymptomatic adults (Figure 4).

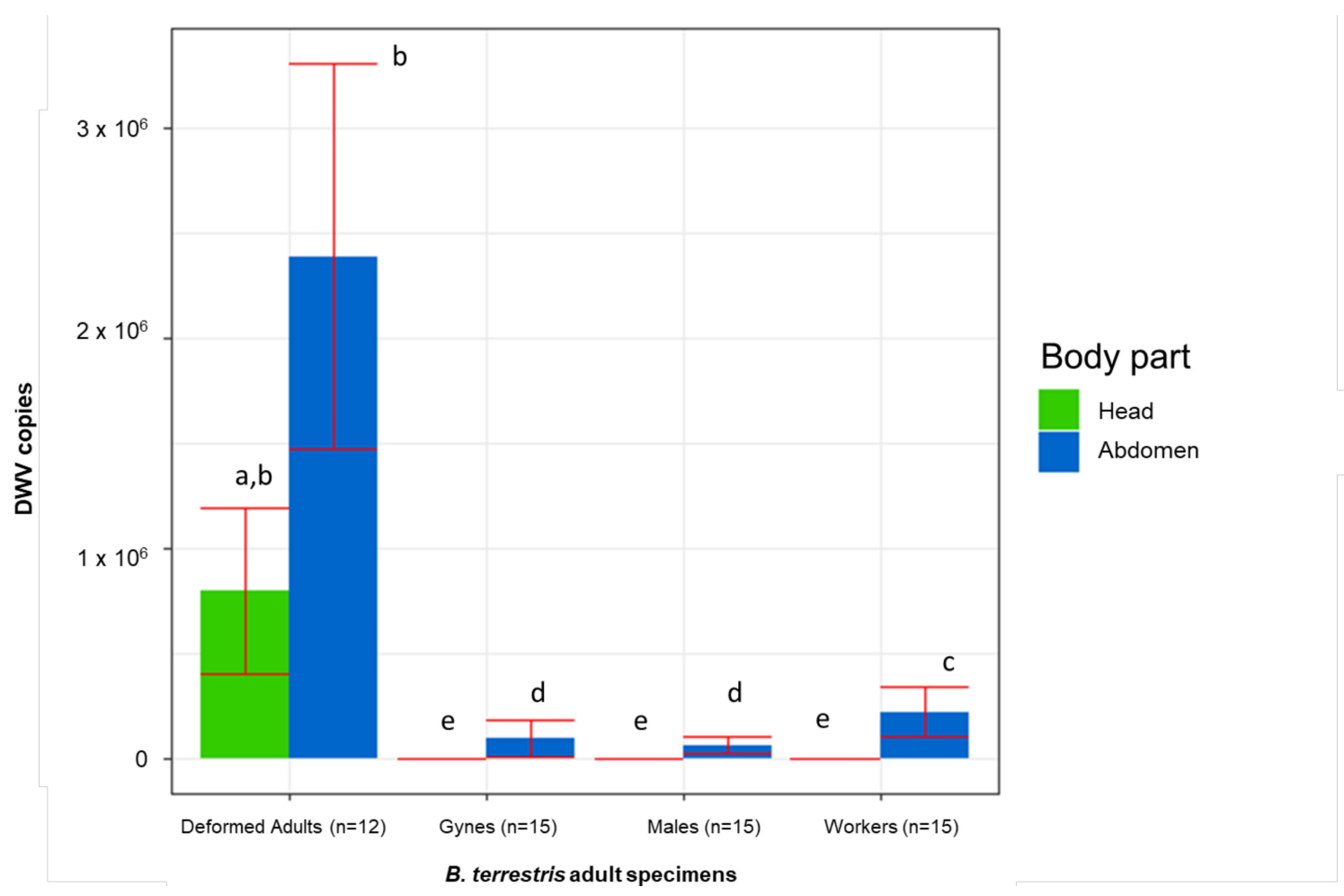

Figure 4. DWV copies detected in both head and rest of the body of deformed and asymptomatic B. terrestris adults. Averages (columns) and standard errors (vertical bars) are shown. The same letters highlight nonsignificant differences $(p \leq 0.05)$.

The strand-specific PCR demonstrated the active DWV replication in all tested samples. The BLAST analysis performed on the obtained amplicons confirmed the specificity of the sequences, with high similarity ( $99 \%$ of percent identity, 0.0 of E-value, $100 \%$ of Query Cover) to specific DWV genomes deposited in GenBank. The same sequence was recorded in all positive samples. The phylogenetic analysis and pairwise distance analysis indicated the highest homology to DWV strains isolated from A. mellifera in the United Kingdom (Figure 5). 


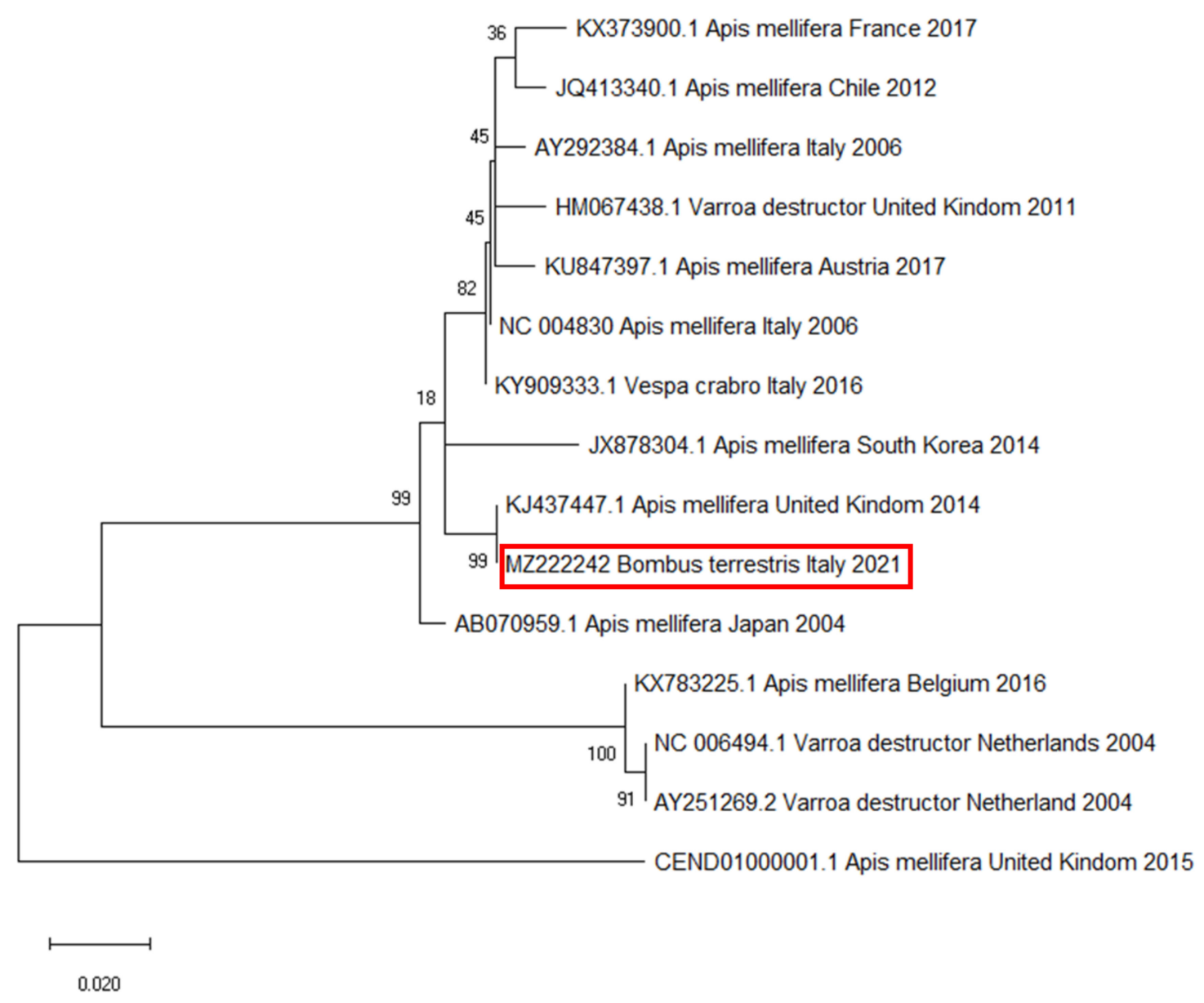

Figure 5. Molecular phylogenetic analysis for RNA-dependent RNA polymerase of deformed wing virus (DWV) by maximum likelihood method. The evolutionary history was inferred using the maximum likelihood method based on the Tamura-Nei model. The branch lengths of the tree measured the number of substitutions per site. The analysis involved 28 nucleotide sequences. There were 255 positions in the final dataset. Accession number, host, state, and year of available GenBank DWV sequences are shown. DWV sequence accession numbers are reported and associated with year and site of origin. The DWV sequence obtained from the tested B. terrestris samples is highlighted by a red box.

\section{Discussion}

Several studies highlight that bees other than A. mellifera can be infected by the DWV [22,24-26,41,52]. Additionally, the virus has been detected in the hornets Vespa crabro and Vespa velutina [19,20], wasp Vespula vulgaris [53], invasive ant Linepithema humile [21], and beetle Aethina tumida $[27,54,55]$. This shows that spillover may occur between both close superfamilies (Apoidea, Vespidae) and insect species belonging to relatively distant groups.

In Bombus spp., DWV has been found in several instances worldwide and considered a significant factor of decline in both wild and managed bumblebee populations [56,57]. DWV infections have been reported in B. terrestris [25,40,52,58-60], B. pascuorum $[25,41,52,58,60]$, B. impatiens $[24,25,61-63]$, B. atratus $[64,65]$, B. vagans $[24,62], B$. huntii [63], B. ruderatus [59], B. ternarius [24], B. lapidarius, B. lucorum, and B. monticola [40].

Despite the fact that DWV infections are a frequent occurrence in B. terrestris [22,25], symptomatic adults with crippled and deformed wings have been seldom reported. To the best of our knowledge, only B. terrestris queens and B. pascuorum workers have been found showing symptoms linked to DWV infection, reporting replicative viral RNA in the thorax and abdomen [41]. Moreover, in asymptomatic B. hunti, DWV was found in the brain and antennae of wild males and reared males and workers, even if it was not found to be replicative [63]. 
In A. mellifera, DWV is chiefly transmitted by the Varroa mites $[1,6,15,17,22]$. Missing a known vector, in bumblebees, the infections are more likely to propagate by a feeding route through the consumption of contaminated food and trophallaxis.

Indeed, commercial bumblebee producers may use honey bee collected pollen as a protein source to feed the queens and support the colony development $[24,66,67]$. In this respect, fresh frozen pollen has a shown higher effectiveness compared to dry pollen, which makes the first generally preferred to feed both queens and developing colonies [68]. However, the pollen collected by the honey bees may contain pathogens, including viruses [45], which may have likely played a role in developing the infections detected in this study. Although the investigated colonies were fed fresh frozen pollen in our laboratory, they already had adults with crippled wings when they arrived, indicating that possible pollen-mediated DWV infections must have occurred at the breeding site. Furthermore, flowers may become contaminated with DWV when visited by infected honey bees, thus representing sites for interspecific transmission to other pollinators, wild bumblebees included $[16,17,52,69]$.

Additionally, newly emerged honey bee workers may be used in commercial breeding to stimulate bumblebee queens to initiate their nesting activity after hibernation [41], but this method is rarely used as it is less effective in inducing oviposition than the use of the bumblebee pupa [70]. Finally, the vertical transmission is also not to be excluded because a DWV-positive queen could deposit infected eggs, from which infected adults can be born, as suggested by the deformed and positive newly emerged male collected.

The total viral load found in each investigated $B$. terrestris individual is comparable to values measured in asymptomatic honey bees (from $10^{2}$ to $10^{6}$ copies) and lower than the viral titre of symptomatic honey bees ( $>10^{7}$ copies) [16]. In all investigated samples, DWV was found in replicative form, demonstrating its adaptability and capability to replicate in Bombus cells [22,41]. Nonsignificant differences in DWV titre were observed in adults considering the head and the rest of the body separately. As for DWV-positive honey bees [41], the symptomatic bumblebees investigated here were characterized by virus presence in the head. Additionally, our results highlighted a relationship between deformities in adults and the presence of DWV in the head. Previously, the B. terrestris and B. pascuorum specimens with crippled wings only resulted positive for the presence of DWV in the thorax and abdomen, but their head scored negative [41]. Additionally, in asymptomatic artificially infected B. huntii specimens, the DWV was found in the antennae and brain [63]. This study could not clarify whether a relationship existed between DWV infection and abnormal pigmentations in symptomatic individuals.

Although other causes of wing malformation cannot be excluded, they should be seen as most unlikely. Upon arrival at the laboratory, the three colonies showed healthy, well-developed, and without signs of mishandling or malnutrition. The fact that in all the colonies the founder queen had died is not uncommon at this stage of colony development, although conventionally it makes the colonies unsuitable for commercialization. In many insect species, the development of deformed adults can also be caused by thermal shock, but in bumblebee colonies, this usually occurs at the early stages of development, when there are still only few workers tending the brood [71]. However, during the three weeks of observation by our laboratory, the colonies were kept at a constant temperature and humidity and carefully manipulated.

Finally, the phylogenetic analysis highlighted that the obtained DWV amplicons showed high similarity ( $99 \%$ identity) with a DWV sequence isolated from the honey bees in the United Kingdom in 2014 [9], suggesting that DWV could be associated with the commercial origin of colonies.

\section{Conclusions}

The results of this study, other than indicating evidence of DWV infection in B. terrestris specimens causing wing deformities similar to the clinical lesion in honey bees, suggest a relationship between the wing deformities and the virus localization in the head. Further studies are needed to define if a specific organ could be a target in symptomatic bumblebees. 
Furthermore, the high similarity of sequenced amplicons with DWV isolated from honey bees in the United Kingdom indicates the North European origin of the virus and suggests that transmission could occur by contaminated pollen administered to bumblebees. The finding of adults with deformed wings and the premature death of the queen raises the question of to what extent the presence of the virus can be associated with a reduction of vitality at the individual level.

Several studies demonstrate that commercially produced bumblebee colonies can carry multiple infectious parasites, posing a significant risk to other native and managed pollinators through pathogen spillover [72]. Currently, commercial colonies must be accompanied by a parasite-free certification, and rearing facilities may be subject to inspection by the national veterinary services. If the colonies are intended for exportation, the certificates may also cover honey bee parasites and pests (e.g., Varroa destructor, Tropilaelaps spp., Aethina tumida, and American foulbrood) but not honey bee viruses.

The geographical origin of the DWV strains found in our colonies and the fact that most commercial B. terrestris breeding is located in Northern Europe raise concerns about the possible future increase of virus spread by long-range export of infected colonies. This advocates for intensified controls in bumblebee rearing operations and the application of preventive measures against virus spread, such as pollen sterilization by gamma radiation, which has already been proven effective against IAPV present in honey bee-collected pollen [73].

Author Contributions: Conceptualization, G.C. and L.B.; methodology, G.C., L.Z., R.R., and L.B.; investigation, G.C., L.Z., R.R., and L.B.; data curation, G.C., L.Z., R.R., A.N., and L.B.; writingoriginal draft preparation, G.C. and L.B.; writing-review and editing, G.C., L.Z., R.R., A.N., and L.B.; supervision, L.B. All authors have read and agreed to the published version of the manuscript.

Funding: This research received no external funding.

Institutional Review Board Statement: Not applicable.

Informed Consent Statement: Not applicable.

Acknowledgments: The authors are grateful to Marta Barberis of the Department of Biological, Geological, and Environmental Sciences, University of Bologna, for her valuable technical support.

Conflicts of Interest: The authors declare no conflict of interest.

\section{References}

1. De Miranda, J.R.; Genersch, E. Deformed wing virus. J. Invertebr. Pathol. 2010, 103, S48-S61. [CrossRef]

2. Genersch, E.; Aubert, M. Emerging and re-emerging viruses of the honey bee (Apis mellifera L.). Vet. Res. 2010, 41, 54. [CrossRef]

3. McMenamin, A.J.; Genersch, E. Honey bee colony losses and associated viruses. Curr. Opin. Insect Sci. 2015, 8, 121-129. [CrossRef]

4. Steinhauer, N.; Kulhanek, K.; Antúnez, K.; Human, H.; Chantawannakul, P.; Chauzat, M.P.; van Engelsdorp, D. Drivers of colony losses. Curr. Opin. Insect Sci. 2018, 26, 142-148. [CrossRef] [PubMed]

5. Buendía, M.; Martín-Hernández, R.; Ornosa, C.; Barrios, L.; Bartolomé, C.; Higes, M. Epidemiological study of honeybee pathogens in Europe: The results of Castilla-La Mancha (Spain). Span. J. Agric. Res. 2018, 16, e0502. [CrossRef]

6. Martin, S.J.; Highfield, A.C.; Brettell, L.; Villalobos, E.M.; Budge, G.E.; Powell, M.; Nikaido, S.; Schroeder, D.C. Global honey bee viral landscape altered by a parasitic mite. Science 2012, 336, 1304-1306. [CrossRef] [PubMed]

7. Mordecai, G.J.; Wilfert, L.; Martin, S.J.; Jones, I.M.; Schroeder, D.C. Diversity in a honey bee pathogen: First report of a third master variant of the Deformed Wing Virus quasispecies. ISME J. 2016, 10, 1264-1273. [CrossRef]

8. McMahon, D.P.; Natsopoulou, M.E.; Doublet, V.; Fürst, M.; Weging, S.; Brown, M.J.F.; Gogol-Döring, A.; Paxton, R.J. Elevated virulence of an emerging viral genotype as a driver of honeybee loss. Proc. Biol. Sci. 2016, 283, 20160811. [CrossRef] [PubMed]

9. Ryabov, E.V.; Wood, G.R.; Fannon, J.M.; Moore, J.D.; Bull, J.C.; Chandler, D.; Mead, A.; Burroughs, N.; Evans, D.J. A virulent strain of deformed Wing Virus (DWV) of honeybees (Apis mellifera) prevails after varroa destructor-mediated, or in vitro, transmission. PLoS Pathog. 2014, 10, e1004230. [CrossRef]

10. Yue, C.; Schroder, M.; Gisder, S.; Genersch, E. Vertical-transmission routes for deformed wing virus of honeybees (Apis mellifera). J. Gen. Virol. 2007, 88, 2329-2336. [CrossRef]

11. Ball, B.V.; Allen, M.F. The prevalence of pathogens in honey bee (Apis mellifera) colonies infested with the parasitic mite Varroa jacobsoni. Ann. Appl. Biol. 1988, 113, 237-244. [CrossRef]

12. Nordström, S. Distribution of deformed wing virus within honey bee (Apis mellifera) brood cells infested with the ectoparasitic mite Varroa destructor. Exp. Appl. Acarol. 2003, 29, 293-302. [CrossRef] [PubMed] 
13. Shen, M.; Cui, L.; Ostiguy, N.; Cox-Foster, D. Intricate transmission routes and interactions between picorna-like viruses (Kashmir bee virus and sacbrood virus) with the honeybee host and the parasitic varroa mite. J. Gen. Virol. 2005, 86, 2281-2289. [CrossRef] [PubMed]

14. Lanzi, G.; de Miranda, J.R.; Boniotti, M.B.; Cameron, C.E.; Lavazza, A.; Capucci, L.; Camazine, S.M.; Rossi, C. Molecular and biological characterization of deformed wing virus of honeybees (Apis mellifera L.). J. Virol. 2006, 80, 4998-5009. [CrossRef]

15. Gisder, S.; Aumeier, P.; Genersch, E. Deformed wing virus: Replication and viral load in mites (Varroa destructor). J. Gen. Virol. 2009, 90, 463-467. [CrossRef] [PubMed]

16. Mazzei, M.; Carrozza, M.L.; Luisi, E.; Forzan, M.; Giusti, M.; Sagona, S.; Tolari, F.; Felicioli, A. Infectivity of DWV associated to flower pollen: Experimental evidence of a horizontal transmission route. PLoS ONE 2014, 9, e113448. [CrossRef]

17. Mockel, N.; Gisder, S.; Genersch, E. Horizontal transmission of deformed wing virus: Pathological consequences in adult bees (Apis mellifera) depend on the transmission route. J. Gen. Virol. 2011, 92, 370-377. [CrossRef]

18. Chen, Y.; Evans, J.; Feldlaufer, M. Horizontal and vertical transmission of viruses in the honey bee, Apis mellifera. J. Invertebr. Pathol. 2006, 92, 152-159. [CrossRef]

19. Mazzei, M.; Forzan, M.; Cilia, G.; Sagona, S.; Bortolotti, L.; Felicioli, A. First detection of replicative deformed wing virus (DWV) in Vespa velutina nigrithorax. Bull. Insectol. 2018, 71, 211-216.

20. Forzan, M.; Sagona, S.; Mazzei, M.; Felicioli, A. Detection of deformed wing virus in Vespa crabro. Bull. Insectol. 2017, 70, 261-265.

21. Sébastien, A.; Lester, P.J.; Hall, R.J.; Wang, J.; Moore, N.E.; Gruber, M.A.M. Invasive ants carry novel viruses in their new range and form reservoirs for a honeybee pathogen. Biol. Lett. 2015, 11, 20150610. [CrossRef] [PubMed]

22. Gisder, S.; Genersch, E. Viruses of commercialized insect pollinators. J. Invertebr. Pathol. 2017, 147, 51-59. [CrossRef] [PubMed]

23. Gusachenko, O.N.; Woodford, L.; Balbirnie-Cumming, K.; Ryabov, E.V.; Evans, D.J. Evidence for and against deformed wing virus spillover from honey bees to bumble bees: A reverse genetic analysis. Sci. Rep. 2020, 10, 16847. [CrossRef] [PubMed]

24. Singh, R.; Levitt, A.L.; Rajotte, E.G.; Holmes, E.C.; Ostiguy, N.; van Engelsdorp, D.; Lipkin, W.I.; dePamphilis, C.W.; Toth, A.L.; Cox-Foster, D.L. RNA viruses in hymenopteran pollinators: Evidence of Inter-Taxa Virus transmission via pollen and potential impact on non-apis hymenopteran species. PLoS ONE 2010, 5, e14357. [CrossRef]

25. Tehel, A.; Brown, M.J.; Paxton, R.J. Impact of managed honey bee viruses on wild bees. Curr. Opin. Virol. 2016, 19, 16-22. [CrossRef] [PubMed]

26. Ravoet, J.; de Smet, L.; Meeus, I.; Smagghe, G.; Wenseleers, T.; de Graaf, D.C. Widespread occurrence of honey bee pathogens in solitary bees. J. Invertebr. Pathol. 2014, 122, 55-58. [CrossRef]

27. Eyer, M.; Chen, Y.P.; Schäfer, M.O.; Pettis, J.; Neumann, P. Small hive beetle, Aethina tumida, as a potential biological vector of honeybee viruses. Apidologie 2009, 40, 419-428. [CrossRef]

28. Potts, S.G.; Imperatriz-Fonseca, V.; Ngo, H.T.; Aizen, M.A.; Biesmeijer, J.C.; Breeze, T.D.; Dicks, L.V.; Garibaldi, L.A.; Hill, R.; Settele, J.; et al. Safeguarding pollinators and their values to human well-being. Nature 2016, 540, 220-229. [CrossRef] [PubMed]

29. Velthuis, H.H.W.; van Doorn, A. A century of advances in bumblebee domestication and the economic and environmental aspects of its commercialization for pollination. Apidologie 2006, 37, 421-451. [CrossRef]

30. Lecocq, T.; Rasmont, P.; Harpke, A.; Schweiger, O. Improving international trade regulation by considering intraspecific variation for invasion risk assessment of commercially traded species: The Bombus terrestris case. Conserv. Lett. 2016, 9, 281-289. [CrossRef]

31. Colla, S.R.; Otterstatter, M.C.; Gegear, R.J.; Thomson, J.D. Plight of the bumble bee: Pathogen spillover from commercial to wild populations. Biol. Conserv. 2006, 129, 461-467. [CrossRef]

32. Imhoof, B.; Schmid-Hempel, P. Colony success of the bumble bee, Bombus terrestris, in relation to infections by two protozoan parasites, Crithidia bombi and Nosema bombi. Insectes Soc. 1999, 46, 233-238. [CrossRef]

33. Folly, A.J.; Koch, H.; Stevenson, P.C.; Brown, M.J.F. Larvae act as a transient transmission hub for the prevalent bumblebee parasite Crithidia bombi. J. Invertebr. Pathol. 2017, 148, 81-85. [CrossRef] [PubMed]

34. Shykoff, J.A.; Schmid-Hempel, P. Incidence and effects of four parasites in natural populations of bumble bees in Switzerland. Apidologie 1991, 22, 117-125. [CrossRef]

35. Otterstatter, M.C.; Whidden, T.L. Patterns of parasitism by tracheal mites (Locustacarus buchneri) in natural bumble bee populations. Apidologie 2004, 35, 351-357. [CrossRef]

36. McMenamin, A.J.; Flenniken, M.L. Recently identified bee viruses and their impact on bee pollinators. Curr. Opin. Insect Sci. 2018, 26, 120-129. [CrossRef]

37. Meeus, I.; de Miranda, J.R.; de Graaf, D.C.; Wäckers, F.; Smagghe, G. Effect of oral infection with Kashmir bee virus and Israeli acute paralysis virus on bumblebee (Bombus terrestris) reproductive success. J. Invertebr. Pathol. 2014, 121, 64-69. [CrossRef] [PubMed]

38. Pascall, D.J.; Tinsley, M.C.; Clark, B.L.; Obbard, D.J.; Wilfert, L. Virus prevalence and genetic diversity across a wild bumblebee community. Front. Microbiol. 2021, 12. [CrossRef]

39. Wang, H.; Meeus, I.; Piot, N.; Smagghe, G. Systemic Israeli acute paralysis virus (IAPV) infection in bumblebees (Bombus terrestris) through feeding and injection. J. Invertebr. Pathol. 2018, 151, 158-164. [CrossRef]

40. Fürst, M.A.; McMahon, D.P.; Osborne, J.L.; Paxton, R.J.; Brown, M.J.F.F. Disease associations between honeybees and bumblebees as a threat to wild pollinators. Nature 2014, 506, 364-366. [CrossRef]

41. Genersch, E.; Yue, C.; Fries, I.; de Miranda, J.R. Detection of Deformed wing virus, a honey bee viral pathogen, in bumble bees (Bombus terrestris and Bombus pascuorum) with wing deformities. J. Invertebr. Pathol. 2006, 91, 61-63. [CrossRef] 
42. Radzevičiūtè, R.; Theodorou, P.; Husemann, M.; Japoshvili, G.; Kirkitadze, G.; Zhusupbaeva, A.; Paxton, R.J. Replication of honey bee-associated RNA viruses across multiple bee species in apple orchards of Georgia, Germany and Kyrgyzstan. J. Invertebr. Pathol. 2017, 146, 14-23. [CrossRef] [PubMed]

43. Alger, S.A.; Burnham, P.A.; Boncristiani, H.F.; Brody, A.K. RNA virus spillover from managed honeybees (Apis mellifera) to wild bumblebees (Bombus spp.). PLoS ONE 2019, 14, e217822. [CrossRef] [PubMed]

44. Manley, R.; Temperton, B.; Doyle, T.; Gates, D.; Hedges, S.; Boots, M.; Wilfert, L. Knock-on community impacts of a novel vector: Spillover of emerging DWV-B from Varroa-infested honeybees to wild bumblebees. Ecol. Lett. 2019, 22, 1306-1315. [CrossRef]

45. de Sousa Pereira, K.; Meeus, I.; Smagghe, G. Honey bee-collected pollen is a potential source of Ascosphaera apis infection in managed bumble bees. Sci. Rep. 2019, 9, 1-9. [CrossRef]

46. Bogo, G.; de Manincor, N.; Fisogni, A.; Galloni, M.; Bortolotti, L. Effects of queen mating status, pre-diapause weight and pupae's sex on colony initiation in small-scale rearing of Bombus terrestris. Apidologie 2017, 48, 845-854. [CrossRef]

47. Cilia, G.; Cabbri, R.; Maiorana, G.; Cardaio, I.; Dall'Olio, R.; Nanetti, A. A novel TaqMan ${ }^{\circledR}$ assay for Nosema ceranae quantification in honey bee, based on the protein coding gene Hsp70. Eur. J. Protistol. 2018, 63, 44-50. [CrossRef]

48. Cilia, G.; Sagona, S.; Giusti, M.; dos Santos, P.E.J.; Nanetti, A.; Felicioli, A. Nosema ceranae infection in honeybee samples from Tuscanian Archipelago (Central Italy) investigated by two qPCR methods. Saudi J. Biol. Sci. 2019, 26, 1553-1556. [CrossRef]

49. Chen, Y.P.; Higgins, J.A.; Feldlaufer, M.F. Quantitative real-time reverse transcription-PCR analysis of deformed wing virus infection in the honeybee (Apis mellifera L.). Appl. Environ. Microbiol. 2005, 71, 436-441. [CrossRef]

50. Altschul, S.F.; Gish, W.; Miller, W.; Myers, E.W.; Lipman, D.J. Basic local alignment search tool. J. Mol. Biol. 1990, 215, 403-410. [CrossRef]

51. Kumar, S.; Stecher, G.; Li, M.; Knyaz, C.; Tamura, K. MEGA X: Molecular evolutionary genetics analysis across computing platforms. Mol. Biol. Evol. 2018, 35, 1547-1549. [CrossRef]

52. Dalmon, A.; Diévart, V.; Thomasson, M.; Fouque, R.; Vaissière, B.E.; Guilbaud, L.; le Conte, Y.; Henry, M. Possible spillover of pathogens between bee communities foraging on the same floral resource. Insects 2021, 12, 122. [CrossRef]

53. Brenton-Rule, E.C.; Dobelmann, J.; Baty, J.W.; Brown, R.L.; Dvorak, L.; Grangier, J.; Masciocchi, M.; McGrannachan, C.; Shortall, C.R.; Schmack, J.; et al. The origins of global invasions of the German wasp (Vespula germanica) and its infection with four honey bee viruses. Biol. Invasions 2018, 20, 3445-3460. [CrossRef]

54. Huwiler, M.; Papach, A.; Cristina, E.; Yañez, O.; Williams, G.R.; Neumann, P. Deformed wings of small hive beetle independent of virus infections and mites. J. Invertebr. Pathol. 2020, 172, 107365. [CrossRef] [PubMed]

55. Nanetti, A.; Ellis, J.D.; Cardaio, I.; Cilia, G. Detection of Lotmaria passim, Crithidia mellificae and replicative forms of deformed Wing Virus and Kashmir Bee Virus in the Small Hive Beetle (Aethina tumida). Pathogens 2021, 10, 372. [CrossRef] [PubMed]

56. McMahon, D.P.; Fürst, M.A.; Caspar, J.; Theodorou, P.; Brown, M.J.F.; Paxton, R.J. A sting in the spit: Widespread cross-infection of multiple RNA viruses across wild and managed bees. J. Anim. Ecol. 2015, 84, 615-624. [CrossRef]

57. Meeus, I.; Brown, M.J.F.; de Graaf, D.C.; Smagghe, G. Effects of invasive parasites on bumble bee declines. Conserv. Biol. 2011, 25, 662-671. [CrossRef]

58. Jabal-Uriel, C.; Martín-Hernández, R.; Ornosa, C.; Higes, M.; Berriatua, E.; de la Rua, P. First data on the prevalence and distribution of pathogens in bumblebees (Bombus terrestris and Bombus pascuorum) from Spain. Span. J. Agric. Res. 2017, 15, e05SC01. [CrossRef]

59. Arismendi, N.; Riveros, G.; Zapata, N.; Smagghe, G.; González, C.; Vargas, M. Occurrence of bee viruses and pathogens associated with emerging infectious diseases in native and non-native bumble bees in southern Chile. Biol. Invasions 2021, 1-15. [CrossRef]

60. Evison, S.E.F.; Roberts, K.E.; Laurenson, L.; Pietravalle, S.; Hui, J.; Biesmeijer, J.C.; Smith, J.E.; Budge, G.; Hughes, W.O.H. Pervasiveness of parasites in pollinators. PLoS ONE 2012, 7, e30641. [CrossRef] [PubMed]

61. Sachman-Ruiz, B.; Narváez-Padilla, V.; Reynaud, E. Commercial Bombus impatiens as reservoirs of emerging infectious diseases in central Mexico. Biol. Invasions 2015, 17, 2043-2053. [CrossRef]

62. Levitt, A.L.; Singh, R.; Cox-Foster, D.L.; Rajotte, E.; Hoover, K.; Ostiguy, N.; Holmes, E.C. Cross-species transmission of honey bee viruses in associated arthropods. Virus Res. 2013, 176, 232-240. [CrossRef]

63. Li, J.; Peng, W.; Wu, J.; Strange, J.P.; Boncristiani, H.; Chen, Y. Cross-species infection of deformed wing virus poses a new threat to pollinator conservation. J. Econ. Entomol. 2011, 104, 732-739. [CrossRef] [PubMed]

64. Gamboa, V.; Ravoet, J.; Brunain, M.; Smagghe, G.; Meeus, I.; Figueroa, J.; Riaño, D.; de Graaf, D.C. Bee pathogens found in Bombus atratus from Colombia: A case study. J. Invertebr. Pathol. 2015, 129, 36-39. [CrossRef]

65. Reynaldi, F.; Sguazza, G.; Albicoro, F.; Pecoraro, M.; Galosi, C. First molecular detection of co-infection of honey bee viruses in asymptomatic Bombus atratus in South America. Braz. J. Biol. 2013, 73, 797-800. [CrossRef]

66. Graystock, P.; Goulson, D.; Hughes, W.O.H. The relationship between managed bees and the prevalence of parasites in bumblebees. PeerJ 2014, 2, e522. [CrossRef] [PubMed]

67. Graystock, P.; Blane, E.J.; McFrederick, Q.S.; Goulson, D.; Hughes, W.O.H. Do managed bees drive parasite spread and emergence in wild bees? Int. J. Parasitol. Parasites Wildl. 2016, 5, 64-75. [CrossRef] [PubMed]

68. Ribeiro, M.F.; Duchateau, M.J.; Velthuis, H.H.W. Comparison of the effects of two kinds of commercially available pollen on colony development and queen production in the bumble bee Bombus terrestris L (Hymenoptera, Apidae). Apidologie 1996, 27, 133-144. [CrossRef] 
69. Yañez, O.; Piot, N.; Dalmon, A.; de Miranda, J.R.; Chantawannakul, P.; Panziera, D.; Amiri, E.; Smagghe, G.; Schroeder, D.; Chejanovsky, N. Bee viruses: Routes of infection in hymenoptera. Front. Microbiol. 2020, 11, 943. [CrossRef]

70. Gurel, F.; Gosterit, A. Effects of different stimulation methods on colony initiation and development of Bombus terrestris L. (Hymenoptera: Apidae) queens. Appl. Entomol. Zool. 2008, 43, 113-117. [CrossRef]

71. Dalmon, A.; Peruzzi, M.; le Conte, Y.; Alaux, C.; Pioz, M. Temperature-driven changes in viral loads in the honey bee Apis mellifera. J. Invertebr. Pathol. 2019, 160, 87-94. [CrossRef] [PubMed]

72. Graystock, P.; Yates, K.; Evison, S.E.F.; Darvill, B.; Goulson, D.; Hughes, W.O.H. The Trojan hives: Pollinator pathogens, imported and distributed in bumblebee colonies. J. Appl. Ecol. 2013, 50, 1207-1215. [CrossRef]

73. Meeus, I.; Mosallanejad, H.; Niu, J.; de Graaf, D.C.; Wäckers, F.; Smagghe, G. Gamma irradiation of pollen and eradication of Israeli acute paralysis virus. J. Invertebr. Pathol. 2014, 121, 74-77. [CrossRef] [PubMed] 